\title{
6
}

\section{Describing the body, disclosing the person: Reflections of Tetun personhood and social-emotional agency}

\section{Barbara Dix Grimes}

Initially setting out to explore Tetun ${ }^{1}$ emotion terms, I soon realised that such an approach was too limiting for the data I was encountering. First, there were the inevitable problems that arise when a second language (such as English) is used to index the meaning of words in another language (such as Tetun). And, while it was not hard to compile a list of Tetun words and phrases that could be equated with emotion terms (in English), I found no overarching category in Tetun equivalent to the notion of 'emotions', making it analytically unsound to speak of Tetun 'emotion terms' as if they constitute an emic category. So, rather than force Tetun concepts into Western culture-bound notions of emotion,

\footnotetext{
1 The Tetun speakers who graciously taught me their language and provided data for this chapter are from the two regencies (kabupaten) of Belu and Malaka in the Indonesian province of Nusa Tenggara Timur on the western side of the Indonesian border with Timor-Leste. There are around 500,000 native speakers of Tetun in these two regencies, with the boundary between the two roughly dividing the two major dialects: Foho in the north and Fehan in the south. This variety of Tetun is also spoken in Timor-Leste, where it is often referred to as 'Tetun Terik', in contrast with the variety of Tetun spoken in and around Dili. I am especially grateful to Gabriel A. Bria, Asnat Halek-Dami, Ludofikus Bria and Emanuel Seran, who worked with me periodically over several years. Charles Grimes provided helpful comments on earlier drafts of this chapter.
} 
I shifted from a focus on emotion terms per se to an analysis of how Tetun speakers talk about inner subjective experience, and what this implies in terms of the conceptualisation of personhood and human agency.

The starting point for analysis thus became what I refer to as Tetun body talk-phrases describing parts of the body that are used when talking about inner subjective experiences such as feeling, thinking, remembering and relating socially. ${ }^{2}$ In the first section of this chapter, I discuss phrases based on seven different body parts that I have found to be at the core of Tetun body talk. I demonstrate how body talk describes the condition or state of a person without disassociating the physical body from the emotional, intellectual or social person. In the second section of the chapter, I note how body talk is linguistically encoded as noun phrases, disclosing the state of the inner person as a non-agent, in contrast to a set of Tetun 'emotion' verbs that assert social-emotional agency. In the third section, I discuss how morality and social norms are emotionally regulated and restrained through the Tetun concept of shame (moe).

\section{The noun phrases of body talk}

Tetun body talk shows considerable similarities with what is found in other languages in the region, including in both Austronesian and Papuan languages. In contrast to the seven body parts found in Tetun body talk, Papuan languages appear to use particularly large inventories of body parts. Kratochvil and Delpada (2012) list 22 different body parts found in 'emotion and cognition predicates' of Abui, a Papuan language of Alor Island just north of Timor. Their database includes over 300 expressions based on these body parts. McElhanon (1977) lists 28 body parts that occur in 'idioms' in Selepet, a Papuan language of Morobe Province in Papua New Guinea. ${ }^{3}$ He comments that 'body parts express definite

2 This use of body metaphors parallels some of what Fox (Chapter 5, this volume) describes for Rote, Sather (Chapter 3, this volume) for Iban and Kuehling (Chapter 7, this volume) for Dobu, along with other works discussed in this chapter.

3 These are amun ('buttocks'), ândâp ('ear'), bât ('hand, arm'), biwi ('inside'), dihin ('chest'), engat ('neck'), hahit ('bone'), hâk ('skin'), hâme ('nose'), hep ('blood'), kahapon ('breath, vapour'), kambe ('shoulder'), kambiam ('liver, heart'), kâa ('foot, leg'), kâkkâ ('molar'), kun ('head'), lau ('mouth'), nâygân nâygân ('understanding'), nekam ('chin'), nelâm ('mind'), nimbilam ('tongue'), sât ('tooth'), sen ('eye'), tâp ('saliva'), tep ('belly'), umut ('shadow, image, spirit'), we ('soul'[?]) and wât ('strength'). 
psychological and sociological functions' and 'a careful study of the expressions based upon body parts reveal[s] an underlying system with some clearly discernible characteristics' (McElhanon 1977: 117).

McElhanon also addresses the difficulty in trying to classify these expressions as having 'idiomatic' (metaphorical or figurative) meaning in contrast to 'non-idiomatic' (literal) meaning.

The same dilemma could be said to exist in Tetun. Some expressions appear to be used metaphorically or figuratively, such as the phrase laran malirin ('cool insides'), which is used to refer to someone who is no longer angry. But other expressions refer to a literal observable state of the body as well as an implied internal state, such as the phrase nawan naksetik ('tight/constricted breathing'), used to refer to someone who is frustrated. In this analysis, I do not attempt to distinguish metaphorical from literal meaning, opting instead to see Tetun body talk-metaphorical or otherwise-as describing and revealing both the body and the person. The Tetun concept of personhood is an embodied one, where physical as well as emotional, intellectual and relational states are revealed by talking about the body/person. Body talk simultaneously references both physical (literal) and metaphorical (figurative) states, without creating distinction between the body and the person.

Phrases based on the seven body parts that have been found in Tetun body talk are discussed below. I include example sentences to show how 'body talk' is grammatically represented as descriptive phrases that define the body/person in systematic ways. The Tetun body parts I elaborate on are listed briefly below; a fuller discussion with examples is given below for a more complete sense of what these simple glosses represent.

nawa-n: 'breath, life force'

ibu-n: 'mouth'

mata-n: 'eye'

ate-n: 'liver'

kakutak: 'brain'

neo-n: 'mind'

lara- $n$ : 'insides' 
Most of the examples below use the following grammatical frame: subject, ${ }^{4}$ [is being described as] body part noun + modifier. ${ }^{5}$

\subsection{Nawan ('breath, life force')}

01 Nia nawan sa'e He breath ascend/increase

02 Nia nawan aat He breath bad/evil

03 Nia nawan naruk He breath long

\section{Nia nawan tuun} He breath descend/subside

Emi baa, te nawan tuun tian You-pl go, reason his breath descend already

05 Nia nawan badak He breath short

06 Nia nawan naksetik He breath tight/constricted

07 Hakraik nawan lai! Lower breath imperative

08 Nia nawan kotu He breath cut/severed

09 La noo nawan NEG exist breath

10 La noo nawan tian NEG exist breath already
'He is angry'

'He has numerous negative social characteristics'

1) 'He is an athletic runner or diver who holds his breath a long time' OR

2) 'He is a person who took an unexpectedly long time to die'

1) 'He is no longer angry' (resulting state)//'His anger is subsiding' (process) OR

2) 'His breath/life force subsides' ${ }^{6}$

'Just go ahead and go, since he's no longer angry [at you]'

'He is quick to get angry'

'He is extremely angry and frustrated'

'Stop being angry!'

'He stopped breathing' (Euphemism: he died—refers to the moment of a person's death $)^{7}$

'There is no breath/life force' (refers to inanimate objects)

'There is no longer any breath/life force' (refers to a dead person or animal)

$4 \mathrm{Nia}$, the Tetun third person singular pronoun, is not marked for gender. For simplicity and brevity, I only gloss it in English with the male pronoun he/him.

5 This sentence is technically composed of a subject and a nonverbal predicate.

6 This phrase is also used to mean a liurai ('king') has died, in the special Tetun register used for talking to/about nobles. The normal phrase used when someone dies, Nia nawan kotu, is considered too impolite for talking about nobles.

7 Similar to the term putus nafas used in the local variety of Malay. 
The link between 'breath' and 'life force' in these Tetun phrases reflects the association between breath and life-an association common in many languages, including English. But, as the phrases about increasing and decreasing anger suggest, in Tetun there is also a close association between the physical state of a person's breathing and the state of his/her emotional and social experience. Nawan sa'e ('breath ascends') is a multidimensional term that simultaneously implies the physiological experience of rapid breathing, the emotional experience of anger and the social experience of troubled relationships.

\subsection{Ibun ('mouth')}

11 Nia ibu wa-waan He mouth DUP-open

12 Nia ibun boot He mouth (n) big

13 Nia ibun maweek He mouth watery

14 Nia nakmulis ibun He twists mouth

15 Nia ibun naruk, nunun naruk He mouth long lips long

16 Nia ibun luan He mouth wide

17 Lia nia keke ti'an nosi ibun baa ibun

Matter its spread already from mouth go/to mouth

18 Loke ibun Open mouth

19 Taka ibun Close mouth

20 Daka ibun Guard mouth

21 Ibun-nanaan Mouth-tongue

22 Nanaan karuak Tongue doubled
'He is amazed/astonished/agape'

'He talks too much, without anything constructive to say' (seen as a negative characteristic such as grandstanding or bragging)

'He frequently gossips'

'He is mocking someone'

'He habitually talks badly about people'

'He is talkative' (descriptive, not negative)

'The news has spread all over the place'

'Begin to talk' (again, after not talking)

'Resume speaking'

'Refuse to talk' (descriptive) OR

'Shut up!' (imperative)

'Be careful what one says'

'A spokesperson'

'Hypocritical, say one thing, then another thing' 
In the parallelisms associated with ritual speech, ibun ('mouth') pairs with nanaan ('tongue'), and the 'mouth-tongue' pair functions as an idiom for a spokesperson, reflecting the physiological association of mouth with speaking. The other phrases show how Tetun body talk of ibun ('mouth') and nanaan ('tongue') reveals the person as a social person.

\subsection{Matan ('eye')}

23 Sia titu ema nodi mata baluk dei

They look person with eye one side only

24 Nia mata katar He eye itch

25 Nia mata malaik He eye quick

26 Nia mata mareek He eye seeing
'They do not treat people appropriately' (they look down on people, view them disparagingly, treat people with contempt)

'He habitually flirts with girls'

'His eyes move quickly' (Implication: to look at or flirt with girls)

'He sees things in the invisible world'

As the above examples show, Tetun body talk of eyes reflects ways of seeing and interacting with the external social worlds, including the invisible world.

\subsection{Aten ('liver')}

27 Ema née, ate kabahat Person this liver stingy/ miserly

28 Ema ne'e, ate fa'ek Person this liver split

29 Ema née, ate kamoruk Person this liver bitter
'This person is very selfish/unsharing/
stingy'

'This person is self-centred and causes social divisions'

'This person acts extremely egotistically and bitter towards other people'

My Tetun consultants were quick to point out that, unlike Indonesian and the local variety of Malay, in Tetun there are only a limited number of body-talk phrases relating to aten ('liver') and these phrases always portray characteristics that are viewed very negatively. The liver is considered to be located deeply within a person, both physically and socially. When traits such as stingy, divisive and bitter are associated with a person's liver, these traits are considered 'deep' and almost never changeable. 


\subsection{Kakutak ('brain')}

30 Nia kakutak diak He brain good

31 Nia kakutak kro'at He brain sharp

32 Nia kakutak loos He brain straight

33 Nia kakutak monas He brain hard

34 Nia kakutak ufak He brain dull

35 Nia kakutak ktomak He brain complete

36 Mak bolu lia rai lia iha kakutak

REL calls out word store word in brain

37 Lia nia la tama baa kakutak Matter its NEG enter go/to brain
'He thinks/remembers well/He is a good thinker/He is clever'

'He thinks/remembers perceptively'

'He thinks/remembers correctly/wisely/ accurately' (the metaphor of straight implies a contrast to the negative association of twisted/devious)

'He is dull-witted, can't remember and respond appropriately to what people tell him'

'He is stupid' (he should remember and respond but does not)

'He is very stupid' (his brains are complete or closed-not open to comprehend or respond to new information)

A traditional poet is 'one who stores up knowledge in his brain'

'That matter does not make sense'

The above examples show that kakutak ('brains') are conceptualised as the place where information and memories are located. As with other parts of the body, brains can be described in a variety of ways, indexing how a person remembers mentally and how they respond socially to information they are expected to know. Interestingly, kakutak ('brains') contrasts with neon ('mind'), described below.

\subsection{Neon ('mind/heart')}

Phrases with the noun neo- $n$ are numerous. Some of the phrases refer to thinking, pondering or coming to a mental conclusion about something, and can be translated with an English gloss like 'mind'. However, many neon phrases could also be considered typical emotion terms, more fitting 
with an English gloss of 'heart' as the seat of emotions and values. This is a significant point: neon is best translated as both 'mind' and 'heart' - the place for both thinking and feeling.

Tetun speakers agree that the neon is an internal part of the body (often pointing to their chest), but they also agree that there is no physical organ called neon. In butchering a pig, for example, there would be no neon to point out, in contrast to the previous phrases used above to describe Tetun body talk.

The root of the noun neo- $n$ is neo, which can appear as the verb ha-neo, meaning to 'reason' or 'think'. Neon is where the action of haneo occurs.

38 Ita haneo iha neon 'We think in our mind/heart'

We-inc think in mind/heart

39 Naree nu'unia, sia naneo na'ak ... 'Seeing like that, they reasoned/ See like that they think saying concluded that ...'

Another verb associated with neon is horan, which focuses on the human ability to 'sense' or 'perceive'. Horan can be associated with what could be considered emotional feelings such as fear, good fortune or unpleasantness, but it also can be associated with sensing bodily 'feelings', such as the adverse experiencing of tiredness, thirst and hunger.

40 Ita horan hatauk iha neon laran We-inc perceive fear in mind inside

41 Ita horan salaen

We-inc perceive thirst

42 Sia horan sotir, tan moris furak They perceive good fortune because live pleasant
'We perceive/sense/experience fear in our mind/heart'

'We experience thirst'/'They are thirsty'

'They experience good fortune, because they live well off

Both haneo and horan are considered characteristics of living human beings.

43 Oras ita moris, ita hatene haneo no horan

When we-inc live we know

think and perceive
'When we are alive, we are able to think and perceive' 
In contrast to the actions of haneo no horan ('thinking and perceiving'), which are associated with the neon ('heart/mind'), the action of hanoin ('remembering') is associated with the kakutak ('brain'). Hanoin can include a sense of yearning for someone or for a socially positive event.

44 Hanoin ba oras emi sei ki’ik Remember to when you-pl still small

45 Ita hanoin iha kakutak We-inc remember in brain

46 Hanoin di'a-di'ak! Remember DUP-good
'Remember when you were still small/ young'

'We remember in our brain'

'Pay attention!'/'Think carefully!'

Remarkably, the Tetun grammatical particle hola ('take', when used as a main verb) collocates with the verb hanoin ('remember'), but does not collocate with haneo ('think'). As a modifier, hola is a perfective verbal marker, indicating that the action of the verb is completed and accomplished. ${ }^{8}$ Semantically, it cannot co-occur with haneo-constrained by the reality that thinking is a continuing process. Remembering, on the other hand, is an action that can be completed or successfully accomplished.

47 Mais la nanoin nola, teki-tekis nia fila mai

But NEG remember take suddenly he return come
'He forgot what he came to do, and just went home' (i.e. he did not successfully remember)

But *naneo nola ('*accomplish thinking') is not allowable in any contexts according to the native speakers of Tetun with whom I consulted.

The following phrases show productive uses of neon.

48 Nia neon diak He mind good

49 Nia neon loos He mind straight

50 Nia neon monas He mind hard
'He is happy/pleased/in a pleasant state of mind'

'He is honest, does what is right'

'He is hard-hearted/not compassionate'

(when the social situation requires it)

8 Readers interested in understanding in greater depth how verbal modifiers such as hola can make the verb perfective with an accomplishment sense are referred to Jacob and Grimes (2011), which describes this in-depth for several languages in the West Timor region. 
51 Niakaan neon kbiit His mind strong

52 Nia neon ktodan He mind heavy

53 Nia neon kii He mind sting

54 Nia neon ki'ik He mind small

55 Nia neon boot He mind big

56 Nia neon susar He mind difficulty

57 Nia neo ruak He mind two

58 Nia neon monu He mind fall

59 Nia neon lakon He mind disappear

60 Nia neon mamar He mind soft/pliable

61 Nia neon noku He mind calm

62 Nia neon kmetis He mind firm

63 Nia neon fatuk He mind rock

64 Nia neon lalek He mind without

65 Nia neon lakon tian He mind disappear already

66 Nia noo neon tian He exist mind already
'He is not fearful or easily swayed to do wrong'

'He is worried, heavy-hearted, sad, discouraged'

'He is troubled, has many concerns'

'He is insecure, petty, not self-confident'

'He is happy, justifiably proud, delighted' 'He is distressed/troubled' (often because of loss due to death or threat of loss)

'He is undecided' (cf. English idiom: 'he is of two minds')

'He becomes disappointed, loses enthusiasm'

'He is temporarily startled, unable to think, panics, freezes'

'He is easily persuaded and does what others say [when he should not]' (children are said to have pliable minds/hearts)

'He is calm, at peace, cool-headed, not worried'

'He is consistent, does not change his mind'

'He is consistent' (similar to 'firm mind/ heart' above)

'He does things thoughtlessly, without caring about others, and without thought to the social consequences'

'He is confused, doesn't know what to think or do'

'He now has a mind/heart' (said of a young child when he begins to express cognition; newborns are considered to not yet have a mind/heart) 
67 Ami hakbiit siakan neon We-exc strengthen their mind

68 Nia taka neon tian He close mind already

69 Nia loke neon tian He open mind already

70 Nia neon dodok He mind shatter

71 Emi lala'o, emi neon moris, o! You-pl walk you mind live EMPH

72 Nia namina aan nola ema neon

He oils self take person mind

73 Keta rai neon baa kro'at no kmeik

Don't store mind go/to sharp and pointed

74 Lia nia, lia neon ain Matter its matter mind foot
'We encourage, strengthen their hearts'

'He refuses to listen to advice or input from others'

'He now responds to advice or input from others'/'He is now receptive to guidance'

'His heart is broken [from failed romantic love]'

'When you are walking/travelling, you must keep your minds alert!'

'He acts in a way to deceive someone'

'Don't put your trust in weapons'

'That matter/story is a secret' (lit.: at the foot of the mind; cf. English concept of 'deepest darkest secret')

Another phrase considered by Tetun speakers to be similar to lia neon ain ('a matter at the foot of the mind/heart') is lia kabu laran ('a matter inside the stomach'). Things that are inside the stomach, or at the foot of the mind/heart, are secret and not known to others; they are hidden in the corners of our inner being, so to speak.

\subsection{Laran ('inside')}

Laran ('inside') is a common Tetun locational term referring to the inside of objects (such as iha uma laran: 'inside the house') and is an important concept used in discourse about emotional and social relations. ${ }^{9}$ Tetun

9 As such, there are parallels with Fox's (Chapter 5, this volume) description of dalek ('inside') for Rote languages. Linguistically, Tetun lara- $n$ and Rote dale- $k$ are cognate, both deriving from ProtoMalayo-Polynesian *dalom ('inside') (C. Grimes, personal communication). Tetun laran ('inside') also contrasts with luan ('outside') in spatial and social ways, similar to Fox's description of Rote dalek ('inside') and de'ak ('outside'). For example, in Tetun, a contrast in the social origin of children is expressed as oa kabun laran ('child from inside the stomach/womb') and oa kabun luan ('child from outside the stomach/womb'). 
speakers agree that, similar to neon ('mind/heart'), laran is internal to the body (and they often point to their chest), but there is also no physical organ called laran. ${ }^{10}$ The following examples show that laran can best be described as the internal reflection of the social person.

75 Nia laran moras

He insides sick

76 Nia laran malirin tian He insides cool already

77 Nia laran maluak He insides wide

78 Nia laran di'ak He insides good
'He is offended/sickened/upset by the actions of another person'

'He is no longer angry'

'He is hospitable, generous, helpful'

'He does good things, does not hold grievances or seek revenge' (cf. English: 'a good-hearted person, a person of good character', but in Tetun it is always with reference to a relation with another person)

It is insightful to contrast the above concept of laran di'ak ('good insides') with the concept of neon di'ak ('good mind/heart') already noted above.

\section{Nia neon diak} He mind good
'He is happy/pleased/in a pleasant state of mind'

These two phrases - both using the descriptive word diak ('good') reveal a significant distinction between the concepts of neon and laran: talk of neon is self-referential, indexing the state of internal experience, while talk of laran is social, indexing the internal state of external social relations. The body talk of laran ('inside') thus indicates that sociality is not constructed as external to the person. Instead, the state of social relations registers 'inside' the body, inside the person.

The fact that neon and laran are both considered integral parts of the body/person provides another indication that Tetun personhood includes inner subjective experiences (such as thinking and feeling) embodied in the neon, as well as social relations embodied 'inside' the body/person.

10 Donohue and Grimes (2008: 148-51) observe comparatively that quite a few Austronesian languages in eastern Indonesia and Timor-Leste have shifted away from the Austronesian words for 'liver' as the seat of emotion and character prevalent in the west (cf. Malay: hati '1. liver, 2. seat of emotions and character'), adapting to follow one of the common Papuan strategies for using 'inside, insides' as the seat of emotion and character. 
In poetic and more eloquent forms of speech, neon and laran are paired to express the notion of doing something enthusiastically, wholeheartedly and unreservedly. In other words, doing something with complete engagement of the inner and social self.

79 Serwisu hodi neon no laran Work with mind and insides

80 Simu hodi neon no laran Receive with mind and insides

81 Sala mak sia nalo la nodi neon no laran

Wrong which they do NEG take mind and insides
'Work wholeheartedly'

'Accept something wholeheartedly'

'Unintentional wrong'

\subsection{Summary of Tetun body talk}

It is now possible to compare, contrast and summarise how Tetun descriptive noun phrases of body talk define the body/person in systematic ways:

- nawan ('breath/life force'): locus for physical and social-emotional states that reveal life and death; registers the danger of anger and frustration

- ibun ('mouth'): locus for oral communication; reflects social-emotional states associated with communication

- matan ('eye'): locus for perception; reveals how the body/person perceives and interacts with the (visible and invisible) social world

- aten ('liver'): locus for semipermanent negatively valued social traits considered to represent flawed character

- kakutak ('brain'): locus for retaining information; indicates how information is processed and remembered as well as appropriate/ inappropriate social responses to memories

- neon ('mind/heart'): locus for thinking, feeling, sensing; reveals numerous social-emotional states

- laran ('inside’): internal reflection of social relations. 


\section{The verbs of social-emotional agency}

The descriptive noun phrases of body talk discussed above describe the condition or state of the body/person and include states that would be clearly classed in English as reflecting 'emotion'. There are also Tetun verbs that can be considered 'emotion' words. These verbs do not refer overtly to the body, but are frequently associated with the social-emotional states that are described through the noun phrases of body talk.

I propose that the differences between the ways these Tetun noun phrases and verbs are encoded in the grammar are significant in the conceptualisation of personhood. Descriptive noun phrases of body talk (body-part noun + modifier) disclose the subject as a non-agent experiencing bodily states such as cool insides, hard brains, a bitter liver and so on. In contrast, when 'emotion' words occur as active verbs, they denote that the subject is acting as an agent doing what I will refer to as 'social-emotional agency'. ${ }^{11}$

This grammatically encoded distinction between experiencing and doing alludes to the analytical distinction made by Strathern (1988: 273) between the Melanesian 'person' and 'agent'. The person is construed from the vantage point of the relations that constitute him or her; she or he objectifies and is thus revealed in those relations. The agent is construed as the one who acts because of those relationships and is revealed in his or her actions.

The active Tetun verbs I discuss below are best understood as involving an agent acting with another in mind. Translations that reflect English notions of emotion can be seriously misleading. Kanarak, for example, is said of a person displaying anger, but to translate kanarak as 'to be angry' is misleading, because kanarak is not a descriptive phrase indicating a subject is experiencing anger; it is an active verb indicating that the subject is doing anger-acting on another as a social-emotional agent.
82 Nia kanarak
He act-in-anger
'He acts in anger towards someone/
He scolds someone'

11 Grammatically, most of the clause-level examples in this chapter follow the simple pattern of subject + predicate. However, there are two kinds of predicates. The noun phrase predicates are nonverbal predicates where the subject is an undergoer in a BE relationship with the quality or characteristic being described in the noun phrase. In contrast, the verbal predicates reflect a DO relationship with the subject as actor. 
A person who does anger in this way can be described with body talk as EXPERIENCING a changed body state:

Nia nawan sa'e

He breath ascend/increase

83 Nia la kanarak ona

He NEG act-in-anger already
'He is angry' (cf. ex. 01)

'He no longer acts in anger towards someone/He no longer scolds someone'

This person can be described with body talk as EXPERIENCING:

Nia nawan tuun

He breath descend

84 Nia kratak

He fiercely-acts-in-anger
'He is no longer angry' (resulting state//'His anger is subsiding' (process) (cf. ex. 04)

'He habitually acts in fierce anger towards someone'

A person who acts in this way can be described with body talk as:

Nia nawan aat

He breath bad/evil
'He has numerous negative social characteristics'/'He has serious issues' (cf. ex. 02)

Other Tetun verbs expressing social-emotional agency include:

85 hasubu complain/grumble

86 hirus express anger/display anger

$\mathbf{8 7}$ rai hirus store anger

88 tinu be jealous 'complain to someone'

'display anger at someone over a period of time' 'store anger towards someone, build up resentment' (waiting for an opportunity to take action/revenge) ${ }^{12}$

'be jealous of someone, act out one's jealousy' (because someone is better than you or has the attention of your spouse/ lover)

12 This is similar, in many ways, to how Malay simpan hati ('hold a grudge'; lit.: store away liver) is used in eastern Indonesia. 
Verbs of positively valued social interaction include:

89 hadomi 'to love, have affection for someone' (Can also imply pity and compassion $)^{13}$

dodan 'to care for someone [often of lower status]'

haloon 'to plead, hope, wait humbly for someone [of higher status] to care of me/us'

hakara 'to like, be fond of someone'

beer 'to sincerely desire, yearn for someone'

The cause or result of these actions can be reflected in the body talk of neon ('mind/heart') and laran ('inside'). When something is done wholeheartedly and unreservedly, the phrase hodi neon no laran ('with $\mathrm{mind} /$ heart and insides') is used, highlighting the efficacy of the actor to act with maximum emotional and social agency.

90 Nia nadomi sia nodi neon no laran

'He loves them wholeheartedly'

He love them with mind and insides

\section{The social-emotional regulation of morality}

The final term I discuss is moe, a term that appeared on my initial list of Tetun emotion terms because it is translated as Indonesian malu, which is often glossed in English with terms ranging from 'shame' to 'embarrassment' to 'shy'. Tetun examples of moe present similarities with Goddard's (1996: 432-5) analysis of Malay malu as a negative and inhibiting reaction to real or potential social disapproval.

Tetun discourse suggests that social life is about knowing when and where to reflect the correct degree of relational restraint or moe. Such knowledge inherently concerns social norms and morality. At one end of the spectrum, respect is required and the restraint of moe is socially necessary. If a person does not show appropriate restraint in the context of a particular relationship, he or she is scolded:

91 Onée, moe lalek

'You are without shame/social restraint'

You this shame without

13 As such, Tetun hadomi shares a similar range of meaning to what Sather (Chapter 3, this volume) describes for Iban concepts of 'love' and Fox (Chapter 5, this volume) describes for the Rote terms sue and suelllai. 
At the other extreme, there are times when people (particularly young children acting 'shy') are seen to inappropriately show excessive social withdrawal or moe. This is termed moe aat ('bad/excessive restraint'). In these cases, the person is told:

92 Lalika moe! 'Don't be so shy/socially withdrawn!'

Unnecessary shame

A sense of boldness can be associated with disregarding moe at times when most people would be too timid.
93 Hảu la kmoe baa
I NEG ashamed go
'I am not too timid/socially restrained
to go' (e.g. get involved in a dispute)

A causative prefix can be added to moe, resulting in a verb causing someone else to become moe.

94 Lia nia na-moe ami Matter its CAUS-shame we-exc
'That matter causes us to become moe' That matter causes us to socially withdraw That matter embarrasses us

Further evidence that moe is a term indicating social and emotional withdrawal can be seen by the addition of the reflexive word aan. Moe aan can be translated as 'embarrass oneself', but it also connotes social retreat or withdrawing oneself.

95 Dadi ema madiduk, ha'u kmoe aan

Become person beg

I shame self
96 Musti hakneter ema nia, nebee nia la moe aan

Must respect person that RESULT he NEG shame self
'Becoming a begging person, I moe myself' (which means both of the following:

'[If I were to] become a beggar, I would socially withdraw myself'

'[If I were to] become a beggar, I would embarrass/shame myself [= be ashamed]')

'[We] must respect that person, so he does not moe himself' (which means both of the following:

'We must respect that person, so he does not socially withdraw himself'

'We must give that person his due respect, so he is not shamed') 


\section{Conclusion: Where have all the emotion terms gone?}

I now return to my initial plan to collect and analyse Tetun emotion terms. The approach was problematic and limiting, because an exclusive focus on emotion did not reveal the broader system underlying Tetun body talk and concepts of the person. The English-centric view of emotion terms as abstract nouns (such as 'happiness', 'anger', 'joy', 'sadness') constructs emotions as feelings distinct from the body. Interestingly, emotion terms in Indonesian - an Austronesian language from the west of Timor-are also frequently expressed as abstract nouns (see Appendix 6.1 for a list of 124 Indonesian emotion terms from Shaver et al. 2001). Less than 10 per cent of the Indonesian emotion terms in this list are based on body-part idioms. In contrast, more than 80 per cent of Tetun terms relating to emotions involve body-part idioms.

In conclusion, Tetun body talk does not encode emotions as abstract nouns or construct emotions as abstract 'feelings'. Rather, inner subject experiences (emotions as well as thoughts, memories and sociality) are embodied and disclosed through body talk by describing the condition manifested or associated with a part of the body. In contrast to the noun phrases of body talk are active verbs grammatically asserting socialemotional agency: the actor acting on and in relation to another. An agent is not construed as experiencing the emotion of anger, but as enacting anger in relation to another. And, as agents act, their social-emotional states are read from their bodies.

\section{References}

Bugenhagen, Robert D. 1990. 'Experiential constructions in MangapMbula'. Australian Journal of Linguistics 10(2): 183-215. doi.org/ 10.1080/07268609008599441.

Donohue, Mark and Charles E. Grimes. 2008. 'Yet more on the position of the languages of eastern Indonesia and East Timor'. Oceanic Linguistics 47(1): 114-58. doi.org/10.1353/ol.0.0008.

Goddard, Cliff. 1996. 'The "social emotions" of Malay (Bahasa Melayu)'. Ethos 24(3): 426-64. doi.org/10.1525/eth.1996.24.3.02a00020. 
Grimes, Barbara Dix. 2010. 'With our hearts and minds: Exploring Tetun emotion terms'. Paper presented to Sixth East Nusantara Conference, Unit Bahasa \& Budaya, Kupang, Indonesia, 5-7 August.

Hemer, Susan R. 2013. Tracing the Melanesian Person: Emotions and relationships in Lihir. Adelaide: University of Adelaide Press. doi.org/ 10.20851/lihir.

Jacob, June and Charles E. Grimes. 2011. 'Aspect and directionality in Kupang Malay serial verb constructions: Calquing on the grammars of substrate languages'. In Claire Lefebvre (ed.) Creoles, Their Substrates, and Language Typology, pp. 337-66. Typological Studies in Language 95. Amsterdam: John Benjamins. doi.org/10.1075/tsl.95.20jac.

Kratochvil, František and Benediktus Delpada. 2012. 'Emotion and cognition predicates in Abui'. Presentation to Current Trends of Linguistic Research of Indigenous Languages in Indonesia International Workshop, Research Institute for Languages and Cultures of Asia and Africa, Tokyo University of Foreign Studies, Tokyo, 18 February.

LeVine, Robert A. (ed.). 2010. Psychological Anthropology: A reader on self in culture. Malden, MA: Wiley-Blackwell.

Levy, Robert I. 1983. 'Introduction: Self and emotion'. Ethos 11(3): 128-34. doi.org/10.1525/eth.1983.11.3.02a00020.

Lutz, Catherine A. 1982. 'The domain of emotion words on Ifaluk'. American Ethnologist 9(1): 113-28. doi.org/10.1525/ae.1982.9.1. $02 \mathrm{a} 00070$.

Lutz, Catherine A. 1989. Unnatural Emotions: Everyday sentiments on a Micronesian atoll and their challenge to Western theory. Chicago: University of Chicago Press.

Lutz, Catherine A. and Geoffrey M. White. 1986. 'The anthropology of emotions'. Annual Review of Anthropology 15: 405-36. doi.org/ 10.1146/annurev.an.15.100186.002201.

McElhanon, Kenneth A. 1977. 'Idiomaticity in a Papuan (nonAustronesian) language'. Kivung 8(2): 103-44.

Myers, Fred R. 1979. 'Emotions and the self: A theory of personhood and political order among Pintupi Aborigines'. Ethos 7: 334-70. doi.org/ 10.1525/eth.1979.7.4.02a00030. 
Senft, Gunter. 1998. 'Body and mind in the Trobriand Islands'. Ethos 26(1): 73-104. doi.org/10.1525/eth.1998.26.1.73.

Shaver, Phillip R., Upekkha Murdaya and R. Chris Fraley. 2001. 'Structure of the Indonesian emotion lexicon'. Asian Journal of Social Psychology 4: 201-24. doi.org/10.1111/1467-839X.00086.

Strathern, Andrew. 1975. 'Why is shame on the skin?' Ethnology 14(4): 347-56. doi.org/10.2307/3773236.

Strathern, Marilyn. 1988. The Gender of the Gift: Problems with women and problems with society in Melanesia. Berkeley, CA: University of California Press. doi.org/10.1525/california/9780520064232.001.0001.

Unit Bahasa dan Budaya. 2013. Maromak Manfatin: Maromak Mamenon Foun no Lia Uluk Fohon hosi Maromak Mamenon Tuan [God's Word: New Testament and Genesis]. Kupang: Unit Bahasa dan Budaya.

van Klinken, Catharina. 1999. A Grammar of the Fehan Dialect of Tetun, an Austronesian Language of West Timor. Pacific Linguistics C-155. Canberra: The Australian National University.

White, Geoffrey M. 2010. 'Moral discourse and the rhetoric of emotion'. In Robert A. LeVine (ed.) Psychological Anthropology: A reader on self in culture, pp. 68-82. Malden, MA: Wiley-Blackwell.

Williams-van Klinken, Catharina. 2007. 'Is he hot-blooded or hot inside? Expression of emotion and character in Tetun Dili'. Paper presented to Fifth East Nusantara Conference, University of Nusa Cendana, Kupang, Indonesia, 1-3 August.

\section{Appendix 6.1: List of 124 Indonesian emotion words}

$\begin{array}{ll}\text { aman } & \text { calmness, safety, security } \\ \text { asik } & \text { absorption, fascination, excitement } \\ \text { asmara } & \text { romantic love } \\ \text { bahagia } & \text { happiness, wellbeing } \\ \text { bangga } & \text { feeling rightfully proud of }\end{array}$


benci

berahi

berang

berani

berat hati

berbesar

berdebar

berdengki

bergaira

besar hati

bimbang

bingung

bosan

cemas

cemburu

ceria

cinta

curiga

damai

demen

dendam

dengki

dongkol

duka

dukacita

edan kesmaran

emosi

frustrasi

gairah

galau

gelisah

gemas hatred, extreme dislike, animosity

sexual desire, lust, infatuation

anger, fury, ire

boldness, courageousness

sadness (lit.: heavy-heartedness)

feeling expanded with pride

heart palpitation, heart flutter

hatred, envy

passion, arousal, enthusiasm

pride, elation

worry, hesitation, vacillation, indecision

confusion; feeling panicky, perplexed, disoriented

boredom; feeling tired of, sick of

worry; feeling disturbed, anxious

jealousy, envy, dissatisfaction

cheerfulness, brightness, purity

love, affection

suspicion, distrust

peacefulness, tranquillity

liking, fondness for

vengeance, bearing a grudge, animosity, rancour

envy, spite

resentment, acrimony; feeling irked, vexed

grief, sorrow, misery

profound sorrow, heartache, grief

being madly in love, infatuated, smitten

negative emotion, feeling seized by emotion

feeling blocked, frustration

passion, strong desire

confusion, upset

nervousness, restlessness, uneasiness, worry, concern

annoyance, irritation (held back) 
gembira

gentar

geram

getar hati

girang

gregetan

gundah

gusar

haru

hasrat

histeris

iba

ikhlas

ingin

iri

jengkel

jenuh

kagum

kalap

kalut

kangen

kasih

kasihan

kawatir

kebat-kebit

kecemasan

kecil hati

keharuan

kemesraan

kepingin gaiety, happiness, cheerfulness, bounciness, enthusiasm

fearful trembling

being infuriated, enraged (growling)

feeling moved (in the heart)

elation, glee, delighted

feeling tense from restraining pent-up emotions

anxiety, restlessness

anxiety, restlessness, agitation, upset

feeling affected, moved, touched, emotional

ardour, passion, longing, desire

feeling hysterically upset

compassion, pity; feeling moved, touched

sincere devotion, complete conviction,

full preparedness

desire, longing

envious resentment

vexation, annoyance, irritation

feeling surfeited, fed up, sick and tired

amazed admiration, respect

beside oneself with anger, possessed, bewitched

confusion, disturbance, inner chaos

confusion, disturbance, inner chaos

affection, love, compassion

pity, merciful compassion

fear, apprehension, worry

nervousness, restlessness, agitation

anxiety, worry, concern, apprehension

hurt, grief, faint-heartedness, discouragement

feeling moved emotionally, affected, touched

intimacy, absorption, love

desire, eagerness for 


$\begin{array}{ll}\text { kepuasan } & \text { satisfaction, contentment } \\ \text { kesal } & \text { feeling peeved, fed up, piqued, cross } \\ \text { lega } & \text { relaxation, relief } \\ \text { malu } & \text { shame, disgrace, mortification } \\ \text { mangkel } & \text { annoyance, irritation } \\ \text { marah } & \text { wrath, anger, ire, fury } \\ \text { mesra } & \text { feeling intimately fused, very close } \\ \text { muak } & \text { loathing, revulsion, repugnance } \\ \text { murka } & \text { anger, fury, feeling incensed } \\ \text { murung } & \text { melancholy, depression, gloom } \\ \text { naik darah } & \text { rising anger, becoming hot-headed } \\ \text { naik pitam } & \text { becoming enraged, having a fit } \\ \text { ngambek } & \text { pouting, anger, sulkiness } \\ \text { panas hati } & \text { edginess; quickness to anger, envy or jealousy } \\ \text { patah hati } & \text { feeling discouraged, heartbroken } \\ \text { pedih hati } & \text { mortification, grief, pain (lit.: stinging, } \\ \text { penyesalan } & \text { smarting heart) } \\ \text { perasaan } & \text { sorrow, regret, remorse } \\ \text { pilu } & \text { feeling, sentiment } \\ \text { prihatin } & \text { sadness, heartache, compassion } \\ \text { puas } & \text { concern, apprehension } \\ \text { putus asa } & \text { satisfaction, complacency } \\ \text { putus harapan } & \text { hopelessness, being dispirited, disconsolation } \\ \text { remuk hati } & \text { hopelessness, despondency, despair } \\ \text { rendah hati } & \text { feeling crushed, broken-hearted } \\ \text { riang } & \text { humility, modesty } \\ \text { rindu } & \text { hilarity, gleefulness, dizziness } \\ \text { risau } & \text { yearning, homesickness } \\ \text { sabar } & \text { restlessness, nervousness, worry } \\ \text { sakit hati } & \text { patience, patient persistence, tolerance, calmness } \\ \text { pain (lit.: hurt heart), displeasure, bitterness }\end{array}$


sayang

sebal

sedih

senang

sendu

senewen

sesal

setia

simpati

suka

sukacita

sukaria

tabah

takut

tenteram

terangsang

terbuai

terkesiap

terpesona

terpikat

tersentuh

tersingung

tertarik

tinggi hati

tulus

waswas

yakin caring, love (also a term of endearment: sweetie, darling)

resentment, vexation

sadness, distress, sorrow, misery

happiness, contentment, liking

sadness, dejection, melancholy

nervousness, having a nervous fit

regret, remorse, sorrow, repentance

loyalty, faithfulness, satisfaction, solidarity

sympathy

liking, fondness for, enjoyment

happiness, joy, merriment

happiness, pleasure, delight, celebration

determination, persistence, steadfastness

fear, apprehension, dread

feeling settled, quieted, reassured

excitement, stimulation, arousal, titillation

blissful oblivion, rapture

being startled, captivated; having one's

attention grabbed

feeling spellbound, enchanted

feeling charmed; attraction, fascination

feeling touched, moved

feeling offended, bitter

attraction, interest

conceit, arrogance

honesty, openness, sincerity, straightforwardness

doubt, anxiety, suspicion, wariness

certainty, conviction, confidence

Source: Indonesian data from Shaver et al. (2001). 
This text is taken from Expressions of Austronesian Thought and Emotions, edited by James J. Fox, published 2018 by ANU Press, The Australian National University, Canberra, Australia.

doi.org/10.22459/EATE.04.2018.06 